\title{
Fracture prevalence of dental crown primary anterior teeth on early childhood education students
}

\author{
Astari Miryasandra*, Inne Suherna Sasmita*, Syarief Hidayat* \\ *Departement of Pedodontics, Faculty of Dentistry, Padjadjaran University
}

\begin{abstract}
Introduction: Teeth injury is a pathological changes in dental hard tissues of the teeth with or without accompanied by damage to surrounding tissue. There are various kinds of trauma to the teeth, one of them is crown fractures. Primary anterior teeth crown fractures is common in children. The aim was to obtain the prevalence of primary anterior teeth crown fractures. Methods: The research was a descriptive study with survey technique. The samples were chosen by cluster random sampling technique. The samples were 315 children who enroll in Early Childhood Education Institution in Cimahi consisting of 139 boys and 176 girls. The prevalence was counted by dividing the numbers of Early Childhood Education students who suffered from crown fracutres with the total numbers of Early Childhood Education students at Cimahi and multiply by a hundred percent. Result: Prevalence of primary anterior teeth crown fractures in Early Childhood Education students in Cimahi is 5.1\%. Conclusion: Prevalence of primary anterior teeth crown fractures in Early Childhood Education students in Cimahi is less than a quarter of the total samples.
\end{abstract}

Keywords : Crown Fractures, Primary Anterior Teeth

\section{INTRODUCTION}

Trauma of primary teeth is a common problem in childhood. ${ }^{1}$ The main causes of dental trauma in children aged 0-4 years mainly because the child fell and usually occurs in the home environment during the day. ${ }^{2}$ The frequency of trauma tends to increase when the child begins to crawl, stand up, learn to walk, and are also associated with lack of motor coordination. ${ }^{3}$

The prevalence of dental trauma in the age group $0-4$ years vary between $10 \%$ to $25 \%{ }^{4}$ Several studies in the United States has declared the prevalence of dental trauma in the group of children aged $5-12$ years at $20 \%-35 \%$, and at the age of 5 years is about one third of the total number of children experience dental trauma. The frequency of dental trauma in boys is slightly more than girls. ${ }^{2}$

The number of boys who experience trauma to the teeth is two times more than the number of girls, because boys typically have more activity than girls, so the risk of injury is higher. ${ }^{5}$ An Arikan research results obtained in 2009 in the Department Pedodontic Ankara University Faculty of Dentistry, showed that of the 51 cases of trauma to primary teeth were found in children 1-7 years of age group, totaling 31 cases found in boys and 20 cases found in girls. ${ }^{6}$ Anterior dental trauma can cause fractures in partial crown. The central incisor teeth and the maxillary lateral teeth fracture have a higher frequency because

Corresponding author: Inne Suherna Sasmita, Department of Pedodontics, Faculty of Dentistry Universitas Padjadjaran, Indonesia. Jalan Sekeloa Selatan I, Bandung, West Java, Indonesia, 40132; Phone: +6222-2504985/2532805 
it was located in the anterior allowing the tooth receiving direct trauma, while the posterior teeth because it is on the back of the oral cavity is more protected than the front teeth that are rarely exposed to trauma. ${ }^{3}$

Research conducted by Mestrinho 1999 in Brazil in 1853 kindergarten peoples aged 1-5 years, $10 \%$ of children aged less than 2 years, $12 \%$ of children aged 3-4 years, and $20 \%$ of children aged 5 years of trauma teeth and $88 \%$ of all cases of dental trauma were found is central incisor tooth fracture on primary maxillary. ${ }^{7}$

Tooth crown fracture mainly occurs in children of preschool age, when children aged 2-5 years, because at this time the child spends most time to play with toys and wants the freedom and space wider to meet the objects that were found, but the child's motor coordination rudimentary easily cause the child to fall and cause injury to the teeth. ${ }^{8,9}$

Research in Indonesia by Sasteria to 1348 children aged 1-12 years at the Children's Clinical Dentistry Faculty of Dentistry, University of Indonesia during the period January 1, 1995 until December 31, 1995 and the results of the study states that 98 children, or for $7.27 \%$ of the entire study population experienced a fracture of the upper anterior teeth crown. ${ }^{10}$

Primary teeth trauma can lead to pain, tooth discoloration, tooth position, some or all crown fracture and loss of teeth from the socket that would interfere with the function and aesthetics of anterior teeth. ${ }^{2}$ this situation if not controlled can cause psychological distress, the child may be shy and low self esteem. ${ }^{11}$

Cimahi is a city that is derived from the status of districts in Bandung Regency in accordance with the development and progress it based on the Law of the Republic of Indonesia Number 5 of 1974 on Government and Regional Autonomy and Government Regulation No. 29 Year 1975 on the Establishment of Administrative City, Cimahi improved status of the sub-district Administrative City in the area of Bandung district led by Mayor Administrative responsible to the district Head of Bandung regency, and in 2001 upgraded to Autonomous City. Cimahi city belongs to the region of West Java Province with an area of $40.36 \mathrm{~km} 2$ and encompass three sub-district consisting of 15 villages namely South Cimahi subdistrict consists of 5 Village, Central Cimahi subdistrict consists of 6 Village, and District of North Cimahi consisting of 4 villages. Cimahi has shown rapid development especially in the field of construction and increase in population, in 2011 the population amounted to 612.168 inhabitants Cimahi, $6.49 \%$ of a group of children aged $0-4$ years, and $9.53 \%$ are groups of children aged 5-9 years, The total number of early childhood education in Cimahi is $215 .{ }^{12}$

So far, there has never been research on the prevalence of anterior crown fracture of primary teeth, especially in the small town population increase quite rapidly with relatively large population of children as in Cimahi. Based on that idea, the authors are interested in doing research on the prevalence of anterior primary tooth crown fracture in Cimahi in 2012. The research objective to obtain the prevalence of anterior primary tooth crown fracture in Early Childhood Education students in Cimahi in 2012.

\section{METHODS}

This type of research is descriptive with survey method and pour the collected data in tabular form (tabulation). The population in the study were all early childhood institutions in Cimahi spread over three districts and 14 villages as many as 215 ECE. The sampling technique used in the study was cluster random sampling with population criteria, namely: ECE in Cimahi, students are enrolled in the early childhood 2-5 years old, students are enrolled in early childhood sex male and female.

Sub-districts selected randomly by researchers to be the location of sampling the District of North Cimahi consisting of four village with a number of early childhood education as many as 29 pieces. ECE sampling of the population in four villages using the formula Slovin (Sugiyono 2009), In order to obtain a sample of 13 ECE. ${ }^{13}$ Furthermore, all 13 pieces of ECE are allocated to four (4) Village by using the appropriate formula. ${ }^{14}$

\section{RESULTS}

Research conducted on 315 children enrolled in 13 institutions of Early Childhood Education (ECE) in Cimahi which consisted of 139 boys and 176 girls. Table 1 shows that most of the sex of early childhood students in Cimahi in 2012 were women, 
as many as 176 people (55.9\%) and the males as much as 139 individuals (44.1\%).

Table 2 shows that most of the students of early in Cimahi childhood education 5-year-old in 2012 as many as 142 people (45.1\%), children aged 4 years as many as 130 people (41.3\%), children aged 3 years as many as 32 people (10.2\%) and children the age of 2 years as many as 11 people (3.5\%). Based on the results obtained by the prevalence of anterior primary tooth crown fracture in Cimahi in 2012 according to the data in Table 3. Research result shows as many as 299 people (94.9\%) ECE peoples in Cimahi the year 2012 was not fractured anterior crown primary teeth and only 16 (5.1\%) underwent anterior crown fracture of primary teeth. In Table 4 . note that

Table 1. The frequency distribution Students ECE in Cimahi by Sex

\begin{tabular}{ccc}
\hline Jenis kelamin & Frekuensi & $\%$ \\
\hline Laki-Laki & 139 & 44.1 \\
Perempuan & 176 & 55.9 \\
\hline Total & 315 & 100.0 \\
\hline
\end{tabular}

of the 139 students boys by 129 votes (40.95\%) there is no anterior crown fracture of primary teeth and 10 (3.17\%) contained anterior crown fracture of primary teeth, while the 176 peoples of children female 170 people (53.97\%) there is no fracture of the anterior primary teeth crowns and $6(1.90 \%)$ contained anterior crown fracture

Table 2. The frequency distribution Students ECE in Cimahi by Age

\begin{tabular}{ccc}
\hline Usia & Frekuensi & $\%$ \\
\hline 2 thn & 11 & 3.5 \\
3 thn & 32 & 10.2 \\
4 thn & 130 & 41.3 \\
5 thn & 142 & 45.1 \\
\hline Total & 315 & 100.0 \\
\hline
\end{tabular}

Table 3. Fracture prevalence of elder Anterior Dental Crown At ECE Peoples in Cimahi

\begin{tabular}{ccc}
\hline Fractures & Frequency & $\%$ \\
\hline No & 299 & 94.9 \\
Yes & 16 & 5.1 \\
\hline Total & 315 & 100.0 \\
\hline
\end{tabular}

Tabel 4. Prevalensi Fraktur Mahkota Gigi Sulung Anterior Pada Murid PAUD di Kota Cimahi Berdasarkan Jenis Kelamin

\begin{tabular}{cccccc}
\hline \multicolumn{7}{c}{ Fraktur Mahkota Gigi } \\
\hline Jenis Kelamin & \multicolumn{2}{c}{ Tidak Ada } & \multicolumn{2}{c}{ Ada } & Total \\
\hline & Frekuensi & $\%$ & Frekuensi & $\%$ & 139 \\
\hline Laki-laki & 129 & 40.95 & 10 & 3.17 & 176 \\
Perempuan & 170 & 53.97 & 6 & 1.90 & 315 \\
\hline Total & 299 & 94.92 & 16 & 5.08 & \\
\hline
\end{tabular}

of primary teeth. Table 5 shows that of the 11 peoples aged 2 years as many as 11 people (3.49\%) underwent anterior crown fracture of primary teeth. 32 students aged 3 years by 1 person
(0.32\%) underwent anterior crown fracture of primary teeth. Of the 130 peoples aged 4 years as many as 7 people (2.22\%) fractured crown anterior primary teeth. Of the 142 peoples aged 5 years

Tabel 5. Prevalensi Fraktur Mahkota Gigi Sulung Anterior Pada Murid PAUD di Kota Cimahi Berdasarkan Usia

\begin{tabular}{|c|c|c|c|c|c|}
\hline \multicolumn{6}{|c|}{ Fraktur Mahkota Gigi } \\
\hline \multirow[t]{2}{*}{ Jenis Kelamin } & \multicolumn{2}{|c|}{ Tidak Ada } & \multicolumn{2}{|c|}{ Ada } & \multirow[t]{2}{*}{ Tota } \\
\hline & Frekuensi & $\%$ & Frekuensi & $\%$ & \\
\hline 2 tahun & 11 & 3.49 & 0 & 0.00 & 11 \\
\hline 3 tahun & 31 & 9.84 & 1 & 0.32 & 32 \\
\hline 4 tahun & 123 & 39.05 & 7 & 2.22 & 130 \\
\hline 5 tahun & 134 & 42.54 & 8 & 2.54 & 142 \\
\hline Total & 299 & 94.92 & 16 & 5.08 & 315 \\
\hline
\end{tabular}


as many as 8 people $(2.54 \%)$ underwent anterior crown fracture of primary teeth.

Table 6 shows that the primary teeth anterior crown fracture largest at 5.1 teeth as much as 6 (37.5\%). Tooth crown fracture 5.2 by 1 person $(6.3 \%)$, tooth 6.1 by 5 people $(31.3 \%)$, tooth 6.2 by 2 votes (12.5\%) and tooth 7.1 by 2

Tabel 5. Prevalensi Fraktur Mahkota Gigi Sulung Anterior Pada Murid PAUD di Kota Cimahi Berdasarkan Usia

\begin{tabular}{ccc}
\hline Jenis kelamin & Frekuensi & $\%$ \\
\hline 5.1 & 6 & 37.5 \\
5.2 & 1 & 6.3 \\
6.1 & 5 & 31.3 \\
6.2 & 2 & 12.5 \\
7.1 & 2 & 12.5 \\
\hline Total & 16 & 100.0 \\
\hline
\end{tabular}

votes $(12.5 \%)$.

\section{DISCUSSION}

Table 1 shows the characteristics of early childhood students in Cimahi, that of the 315 children studied, 179 (55.9\%) of them are girls and $139(44.1 \%)$ boys. The number of samples of early childhood education students are women more than men. Table 2 shows that most of the students of early childhood education in Cimahi in 2012 was 5 years old as many as 142 people (45.1\%), the age of 4 years as many as 130 people $(41.3 \%)$, the age of 3 years as many as 32 people $(10.2 \%)$ and the age of 2 years as many as 11 people (3.5\%). This is according to data from Department of Education Youth and Sports Cimahi (2011), That the population of children of 5-9 years age group more than the population of children of age group $0-4$ years. $^{12}$

Table 3 shows that of the entire study population as many as 299 people (94.9\%) ECE peoples in Cimahi in 2012 did not experience anterior crown fracture of primary teeth and 16 children (5.1\%) underwent anterior crown fracture of primary teeth. The prevalence of crown fracture of primary teeth varies. The prevalence of crown fracture of anterior primary teeth in early childhood students in Cimahi lower when compared to the Brazilian study that states that the prevalence of crown fracture of anterior primary teeth between 10\% -25\% and conducted research in Indonesia Sasteria (1997) On 1348 children aged 1-12 years at the Children's Clinical Dentistry Faculty of Dentistry, University of Indonesia during the period January 1, 1995 until December 31, 1995 which showed 98 children or a total of $7.27 \%$ of the entire study population experienced a fracture of the upper anterior teeth. ${ }^{4,10}$

When compared with the study by Ellis and Davey that shows the prevalence of anterior primary tooth crown fracture in children by $4.2 \%$ , The prevalence of anterior primary tooth crown fracture in Cimahi more tinggi. ${ }^{11}$ Early childhood has several characteristics yatu learning, growth and development is progressive. Child's curiosity can lead to dental trauma. Dental trauma can also occur as a result of parents lacking supervise children while playing, tools, children's games is not safe, setting the location of a child's play is not safe, relating to spatial unsafe for children, for example, there are stairs without safety, floor wet and slippery, the height of the floor is not the same.

Safe playing environment does not cause children easily fall and cause fractures in the teeth, but the risk of dental trauma can be reduced with better parental supervision and identify things that are potentially harmful to children. ${ }^{15}$ Case anterior tooth crown fracture is more common in boys than girls. ${ }^{2}$ Table 4 shows that of the 139 students boys were $10(3.17 \%)$ underwent anterior crown fracture of primary teeth, while 176 peoples from the girls as much as $6(1.90 \%)$ experienced a crown fracture of primary teeth anteriorly.

Comparison of the number of primary teeth anterior crown fracture in the boy is one to two times more than girls, according to research by Garcia-Godoy who gained comparisons anterior crown fracture of primary teeth in boys with a female 1.1: $1 .{ }^{16}$ This is because boys typically have more activity than girls, so the risk of anterior tooth crown fracture was higher in boys (Koch, 2009). ${ }^{3}$ The highest frequency of anterior primary teeth trauma in the age group 0-5 years when the child is 5 years old, about one-third of the total number of children traumatized anterior primary teeth. ${ }^{2}$ As seen in Table 5, from 11 children aged 2 years $(3.49 \%)$ there was no fracture of the anterior primary tooth crown. A total of 32 children 3 years old is $1(0.32 \%)$ with anterior crown fracture of 
primary teeth, as many as 130 children aged 4 years, there were 7 people (2.22\%) had suffered an anterior crown fracture of primary teeth and the frequency of fractures anterior crown primary teeth is highest in children aged 5 years, from 134 children aged 5 years as many as 8 people (2.54\%) underwent anterior crown fracture of primary teeth. Although motor skills, coordination and balance is growing, the risk of tooth trauma increases when children 5 years old because of their increased physical activity of children. ${ }^{17}$ The cause of dental trauma include physical activity, collisions, falls, sports, traffic accidents, violence, use of improper teeth, and at the age of 5 years the main cause of tooth crown fracture of anterior eldest is physical activity. ${ }^{18}$

The occurrence of fracture of the anterior teeth are also supported by the predisposing factors that dentofacial disorders such as type 2 Class I, Class II, Division 1 or overjet more than $3 \mathrm{~mm}$, circumstances weaken teeth like enamel hypoplasia, and children with thumb sucking habit that causes protrusive anterior teeth. ${ }^{11}$ Sweet stated percentage of crown fracture of anterior teeth in the upper jaw is higher than in the lower jaw. ${ }^{18}$ tooth crown fractures occur most commonly on the maxillary central incisor teeth, followed by the maxillary lateral incisor teeth, then central and lateral incisor teeth of the lower jaw. ${ }^{19}$

Table 6 shows the order of species of primary teeth are most often fractured tooth crown. Primary tooth crown fracture of anterior teeth most at 5.1 by 6 people (37.5\%). 5.2 tooth crown fracture as much as $1(6.3 \%)$, tooth 6.15 people (31.3\%), tooth 6.2 by 2 votes (12.5\%) and 7.1 teeth as much as 2 people (12.5\%). The central incisor teeth and the maxillary lateral fracture have a higher frequency because it was located in the anterior and less-protected enabling the tooth receiving direct trauma. ${ }^{3}$

\section{CONCLUSION}

Prevalence of primary anterior teeth crown fractures in Early Childhood Education students in Cimahi is less than a quarter of the total samples.

\section{REFERENCES}

1. Hall D, Williams J, Elliman D. The Child
Surveillance Handbook. 3rd edition. Oxon: Radcliffe Publishing Ltd. 19999

2. Andreasen JO, Andreasen FM, Andersson L. Traumatic Injuries to the Teeth. 4th edition. Odder: Blackwell Publishing Ltd. 2011

3. Koch G. Pediatric Dentistry: A Clinical Approach. Oxford: Blackwell Publishing Ltd. 2009.

4. Cunha RF, Pugliesi DM, Mello VAE. Oral trauma in Brazilian patients aged 0-3 years. Dent Traumatol 2001;171(1):210-212.

5. Andlaw RJ, Rock WP. A Manual of Pediatric Dentistry. 4th edition. London: Churchill Livingstone. 2003

6. Arikan V, Sari S, Sonmez H. The Prevalence and Treatment Outcomes of Primary Tooth Injuries. Eur J Dent. 2010;4(1):447-453.

7. Mestrinho HD, Bezerra ACB, Carvalho JC. Traumatic Dental Injuries in Brazilian Preschool Children. Braz Dent J. 2011;9(2):101-4.

8. Lighter D. 50 Cara Efektif Menanamkan Tingkah Laku Positif Pada Anak. Yogyakarta: Kanisius. 2007

9. Patmonodewo S. Pendidikan Anak Prasekolah. Jakarta: Rineka Cipta. 2000.

10. Sasteria M. Frekuensi Distribusi Fraktur Gigi Anterior Anak yang Datang ke Klinik Ilmu Kedokteran Gigi Anak FKG UI pada Tahun 1995. Skripsi FKG UI. 1997

11. Finn SB. Clinical Pedodontics. 4th edition. Michigan: W.B. Saunders Company. 2003

12. Dinas Pendidikan Pemuda dan Olahraga Kota Cimahi. Data Pokok Pendidikan Wilayah. 2011

13. Sugiyono. Metode Penelitian. Bandung: CV Alphabeta. 2009.

14. Natsir M. Metode Penelitian Bisnis. Jakarta:CV Ghalia. 2005.

15. Puspita WA. Pertolongan Pertama pada Kecelakaan untuk Anak Usia Dini. 2012.

16. Bastone EB, Freer TJ, McNamara JR. Epidemiology of Dental Trauma: A Review of the Literature. Australian Dent 2000;45(1):29.

17. Wong DL. Buku Ajar Keperawatan Pediatrik. Jakarta: EGC. 2008.

18. Grossman LIS, Oliet, Del RCE. Ilmu Endodontik dalam Praktek. Diterjemahkan oleh Abyono R. 11th edition. Jakarta: EGC. 1995

19. Bakland LK. Endodontics. 4th edition. USA: A Waverly Company. 1994 